\title{
ゴルフ場農薬の土壌中における流出挙動
}

\author{
鳥羽 峰樹, 石黒 靖尚, 大野 健治, 近藤 紘之 \\ 福岡県保健環境研究所（T818-01 福岡県太宰府市大字向佐野39）
}

[平成 8 年11月18日受理]

\section{Behaviour of Pesticides in Soil at Golf Links}

\author{
Mineki TOBA, Yasuhisa ISHIGURO, Kenji OHNO and Hiroyuki KONDO \\ Fukuoka Institute of Health and Environmental Sciences \\ (39 Mukaizano, Dazaifu, Fukuoka 818-01)
}

[Received November 18, 1996]

\begin{abstract}
Summary
In the current investigation of the environmental water pollution by chemical compounds, some kinds of pesticide were detected from well water located in golf links. Among the pesticides detected from well water, terbucarb (2,6-ditert-butyl-p-tolyl methyl carbamate) was detected from $60 \%$ of the samples. To clarify the cause of high detection ratio of terbucarb, the behavior of 5 kinds of pesticide in some soils was examined using column system.

As a result, it was clarified that the mobility of terbucarb in fairway soil was almost same as that of simazine, but in masa (soil of weathered granite) the mobile velocity of terbucarb was faster than that of simazine. This seems to be the reason why terbucarb is frequently detected in the well water.
\end{abstract}

Key words: terbucarb, simazine, golf links, groundwater pollution, efflux of pesticides

\section{1.はじめに}

福岡県では平成 3 年 4 月に施行された「福岡県ゴルフ 場農薬適正使用指導要綱」に基づき，県内の全ゴルフ場 を対象として，ゴルフ場農薬環境影響調査を調整池から の排水及び場内の井戸水について実施した。対象農薬は, 水道水の暫定水質目標が設定されている 30 農薬 ${ }^{1,2)} に$, シマジンの代替品として最近使用量が増加する傾向にあ るジチオピル除草剤を加えた 31 種類とした。その結果, 調査した農薬のうち 9 種類が井戸水から検出された。な かでもテルブカルブは, シマジンなど他農薬と比較して その使用量は特別多くはないが, 調査数 20 件中 12 件と特 異的に井戸水からの検出率が高く, その最高濃度は9.8 $\mu \mathrm{g} / \ell$ と他の農薬に比べて高濃度であった。

そこで，著者らは，井戸水からテルブカルブが特異的 に検出される ${ }^{3.4)}$ 原因を解明するため, テルブカルブの ほか数種の農薬について土壌吸着係数を測定するととも に，Fig. 1 に示したカラム実験装置で土壊からの流出挙 動の違いを検討した。

\section{2. 実験方法}

\section{1 試薬}

使用した農薬は, シマジン, テルブカルブ, プロピザ ミド,ベンチオカーブ及びクロロタロニルが和光純薬製, ジチオピルは日本モンサント株式会社より入手した。ま た, 塩化ナトリウム, $n$-ヘキサン, 酢酸エチル, メタノー 
ル及びアセトンは, 和光純薬の残留農薬試験用を使用し た。

\section{2 土壤吸着係数（バッチ法）}

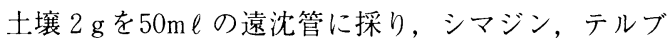
カルブ, プロピザミド, ジチオピル及びベンチオカーブ の混合水溶液 (各 $100 \mathrm{ng} / \mathrm{m} \ell$ ) $40 \mathrm{~m} \ell$ 加え, $20^{\circ} \mathrm{C} て ゙ 4$ 時間振とう後15時間静置した。これを3000 rpmで遠心分 離した後， $0.45 \mu \mathrm{m}$ のメンブランフィルターでろ過し， 万液中の農薬濃度 $\left(\mathrm{C}_{1}\right)$ を定量した。また, 初期濃度 と $\mathrm{C}_{1}$ との差及び土壤の重量から土壤中に残留した農薬 の量と土䁃中の農薬濃度 $\left(\mathrm{C}_{2}\right)$ を求め, 次式により土 袞吸着係数を算出した。

土塞吸着係数 $=\mathrm{C}_{2}(\mathrm{mg} / \mathrm{g}) / \mathrm{C}_{1}(\mathrm{mg} / \mathrm{g})$

\section{3 農薬の土壤からの流出実験（カラム法）}

内径 $20 \mathrm{~mm}$ のガラスカラムに土壤を約 $10 \mathrm{~cm}$ (約 $80 \sim 100 \mathrm{~g}$ ) になるように充填し, その上部に農薬を添着させた少量 の土壌を積層し, 蒸留水を流出速度 $1 \mathrm{~m} \ell / \mathrm{min}$ 以下で通 水した (Fig. 1)。カラムからの流出液を $20 \mathrm{~m} \ell$ ずつ分取 し，それぞれのフラクションに塩化ナトリウム $1 \mathrm{~g}$ を加 え, $n$-ヘキサンー酢酸エチル $(4: 1) 5 \mathrm{~m} \ell$ で抽出し た後, 窒素・リン検出器付きガスクロマトグラフ （GC-NPD）で定量した。

一方, 通水後カラム下部を取り外し, カラム内の土潩 をそのままの状態で柱状に取り出して $2 \mathrm{~cm}$ 毎に 5 分割し て,それぞれについて農薬含有量を次の方法で定量した。 即ち, $100 \mathrm{~m} \ell$ のガラス製遠沈管に土壤（カラム内の土 壤を 5 分割したもの）及びメタノール $20 \mathrm{~m} \ell$ を入れ， 20 分間振とう抽出後, 固液分離し, メタノール層に塩化ナ トリウム $15 \mathrm{~g}$, 水 $40 \mathrm{~m} \ell$ 及び酢酸エチル $20 \mathrm{~m} \ell$ を加えて農

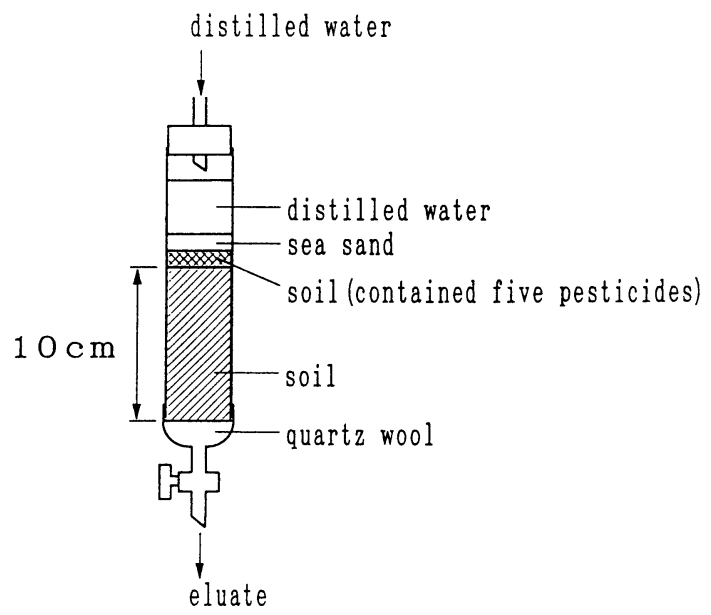

Fig. 1 Experimental device
薬を酰酸エチルに転溶した。酢酸エチル層 $4 \mathrm{~m} \ell$ を正確 に採り, 濃縮乾固した後, 残さを $n$-へキサン（内部標 準として, クロロタロニル $0.5 \mathrm{mg} / \ell$ を含む） $1 \mathrm{~m} \ell$ に溶 解し, GC-NPDで定量した。

なお，使用した農薬は，シマジン，テルブカルブ，プ ロピザミド, ジチオピル, ベンチオカーブの 5 種類で, 実際の散布量を考慮して, それぞれの添着量をシマジン

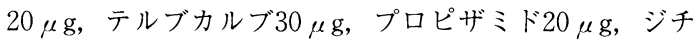
オピル $30 \mu \mathrm{g}$, ベンチオカーブ $20 \mu \mathrm{g}$ とした。猿に添着 させる際使用したアセトンが残留しないようにロー夕 リーエバポレーターを用いて，アセトンを完全に除去し 実験に供した。また，検討した土䁃は，北部九州に広く 分布するマサ土，砂とマサ土の等量混合物，フェアウエ イ土壤（ゴルフ場のフェアウエイの表層約 $10 \mathrm{~cm}$ )，コー ルサンド（石炭の燃え款を粉砕したもの）の 5 種類で, それぞれをふるいにかけて粒径を $2 \mathrm{~mm}$ 以下とした。

\section{4 測定法}

ガスクロマトグラフの条件は，次のと扔りとした。 ガスクロマトグラフ : HP5890

検出器：NPD

カラム : J \& W, DB5, $30 \mathrm{~m} \times 0.25 \mathrm{~mm} \times 0.25 \mu \mathrm{m}$ カラム温度 : $50^{\circ} \mathrm{C}(1 \mathrm{~min}) \rightarrow\left(50^{\circ} \mathrm{C} / \mathrm{min}\right) \rightarrow 200^{\circ} \mathrm{C}(8 \mathrm{~min})$ 注入口及び検出器温度 : $240^{\circ} \mathrm{C}$ キャリアガス:ヘリウム, $1.2 \mathrm{~m} \ell / \mathrm{min}$.

\section{3. 結果及び考察}

\section{1 土墡吸着係数の比較}

結果をTable 1 に示す。それぞれの農薬の土壌吸着 係数は, 土䁃の種類に関倸なく, ジチオピル及びベンチ オカーブが, シマジン，プロピザミド及びテルブカルブ に比較して大きかった。また, 土壤の種類では, コール サンドが特に大きな土壌吸着倸数を示し，次にフェアウ エイ土壤であった。前者の係数が大きな理由は, コール サンドが石炭の燃えがらを粉砕したものであり，吸着表 面積が大きいためと考えられ，後者の場合には，含有さ れる有機物が影響しているものと推定された。

対象農薬の中で，一般的に合剤として使用されるテル ブカルブとシマジンの吸着係数は, フェアウエイ土壤で 若干の差がみられるもののほとんど差異はなく，この結 果からテルブカルブが特異的に地下水から検出される理 由を説明することは出来なかった。

\section{2 カラム実験による農薬の流出挙動}

テルブカルブが特異的に地下水から検出される事実 を，バッチ法による農薬の土壤吸着係数から検証しよう と試みたが前述のとおりであったため，土壤に対する農

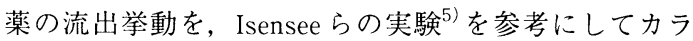


Table 1 Adsorption coefficient of pesticides for each soil

\begin{tabular}{|c|c|c|c|c|c|c|c|}
\hline \multirow{2}{*}{ pesticide } & \multicolumn{5}{|c|}{ soil } & \multirow[b]{2}{*}{ fairway 2} & \multirow{2}{*}{$\begin{array}{c}\text { solubility } \\
\text { (ppm) }\end{array}$} \\
\hline & coal sand & sand & masa & sand + masa & fairway 1 & & \\
\hline simazine & 620 & 0.4 & 4.5 & 1.0 & 2.7 & 2 & 5 \\
\hline terbucarb & 500 & 2.7 & 4.0 & 1.1 & 9.3 & 14 & 7 \\
\hline propyzamide & 1100 & 2.2 & 3.4 & 0.7 & 12 & 11 & 15 \\
\hline dithiopyr & 5900 & 320 & 990 & 460 & 980 & 1600 & 1.4 \\
\hline benthiocarb & 22000 & 58 & 150 & 120 & 520 & 730 & 30 \\
\hline ignition loss(\%) & 1.87 & 0.45 & 2.38 & 1.42 & 8.57 & 5.34 & \\
\hline
\end{tabular}

ム法で検討し，結果をFig. 2〜 5 に示した。マサ土で の各農薬の流出挙動（Fig. 2) では, プロピザミド, ベ ンチオカーブ及びテルブカルブは比較的早い段階に流出 し終えるが, ジチオピル及びシマジンは少量ずつ流出し, 流出終了まで長時間を要することが分かった。この挙動 は，マサ土に砂を混ぜた場合（Fig. 3) も同様の結果で あり,マサ土だけの場合に比較して全体的に流出速度が 速くなったが流出する順序は同じであった。これは，砂 を混ぜることによって平均粒径が大きくなったため接触 面積が低下し，吸着による影響が減少したためと考えら れた。

このようにカラム実験で, 土壤吸着係数が $150 \mathrm{~m} \ell / \mathrm{g}$ と比較的大きなベンチオカーブが非常に早く流出したこ とは，プロピザミド及びテルブカルブの結果を併せ考慮 すると, 水に対する溶解度がカラム内での移動速度に大 きく影響することが推定された。

一方，フェアウエイの土壤の場合（Fig.4，5）は, 場所の異なる2つのゴルフ場から採取した土壤を使用し たが, ともに同様の流出挙動を示し, ジチオピル及びベ ンチオカーブは全く流出せず，プロピザミド及びテルブ カルブの流出速度もかなり遅くなった。しかし，シマジ ンの流出速度はマサ土の場合とほほ同程度か, むしろ早 くなった。このように, マサ土とフェアウエイの上壤で 農薬の流出に差が認められた原因の一つとして土䁃に含 有される有機物量の違いが考えられた ${ }^{6)}$ (Table 1)。 そこで, 有機物含有量の多い腐葉土（有機物含有量：約 30\%）をマサ土に加えた土壤（有機物含有量：約 $6 \%$ ） を用いて農薬の流出挙動を検討した。その結果, Fig. 6 に示すように，ジチオピル及びベンチオカーブは全く流 出せず, シマジン, プロピザミド及びテルブカルブの流 出速度もかなり遅くなり, フェアウエイの土䁃と同様な 流出挙動を示し, 土壤中の有機物が農薬の流出速度に大 きな影響を与えていることが認められた。

\section{3 テルブカルブの地下水検出の特異性}

今回の実験結果では, 農薬のゴルフ場での挙動は, バッ チ法による土塞吸着係数よりもカラム実験の流出挙動の 方が実態と一致する結果が得られた。即ち, 芝生育成や 水はけをよくする目的で土壤改良が行われたフェアウエ イ土壤では, 合剤として散布されたシマジン及びテルブ カルブは, シマジンの方がより早く表層土壤中を移動す るが, 下層の有機物量が少ないマサ土に至ると, シマジ ンの移動速度は非常に遅くなるため, シマジンの多くは 集水管を通して調整池, ゴルフ場外へと流出していくも のと推定された。

一方, テルブカルブは表層フェアウエイ中の有機物に 強く吸着されるため, その移動 (拡散) 速度は遅く, か つ環境での安定性が高いため長期間フェアウエイ中に残 留するが, 一旦マ开土に至るとシマジンとは異なり容易 にマサ土中を移動するため, 带水層にまで到達し, 地下 水中から検出されるものと推定された（Fig. 7 )。

\section{謝 辞}

本研究は「利水過程における農薬等化学物質の動態及 び分解生成物等の評価に関する研究」（厚生省）に於い て実施したもので，多大なるご指導を戴きました国立公 衆衛生院水道工学部真柄部長をはじめ諸先生方に深く感 謝いたします。

\section{要 約}

ゴルフ場農薬による環境水の污染に関する調査におい て, ゴルフ場内の井戸水から数種類の農薬が検出され, 特にテルブカルブは検出率が $60 \%$ と特異的に高かった。 この原因を明らかにするために 5 種類の農薬について， 土袞吸着係数及びカラム法による溶出実験を行った。そ の結果，有機物をより多く含むフェアウエイ表層の土䁃 ではテルブカルブとシマジンの挙動に大きな差は見られ なかったが，フエアウエイ下部の有機物が少ないマサ土 


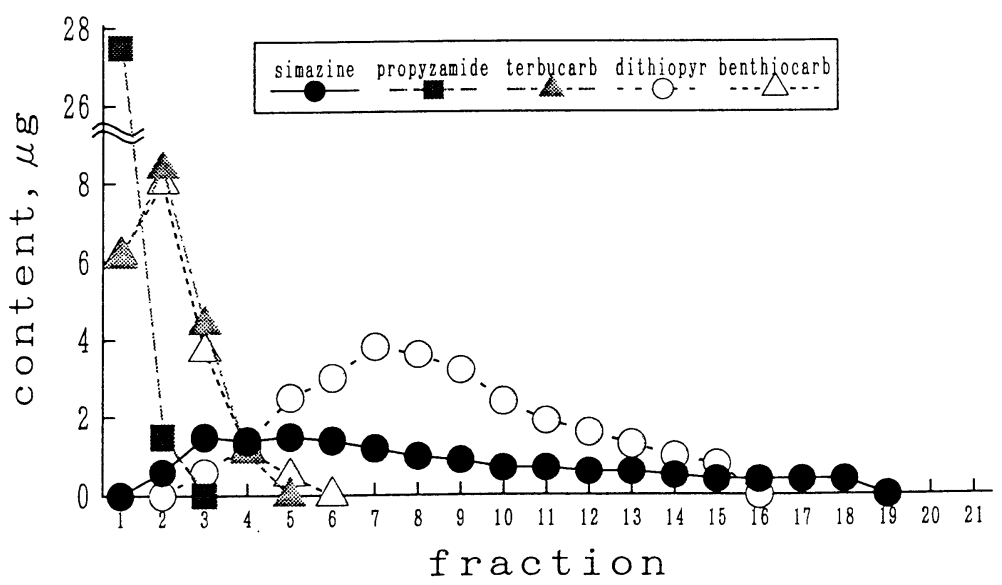

Fig. 2 Efflux behavior of pesticide by column test (in case of masa)

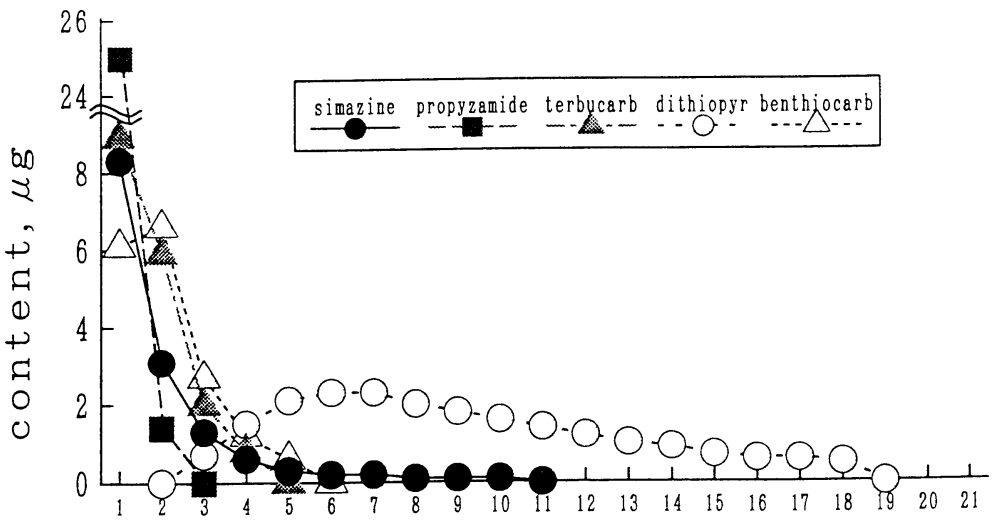

fraction

Fig. 3 Efflux behavior of pesticide by column test (equivalent mixture of masa and sand)

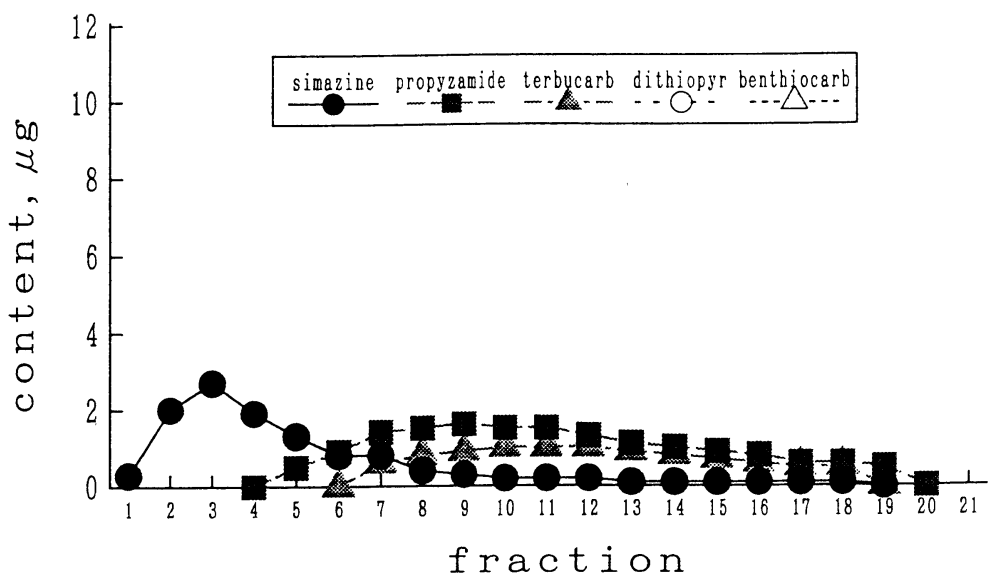

Fig. 4 Efflux behavior of pesticide by column test (in case of fairway 1) 


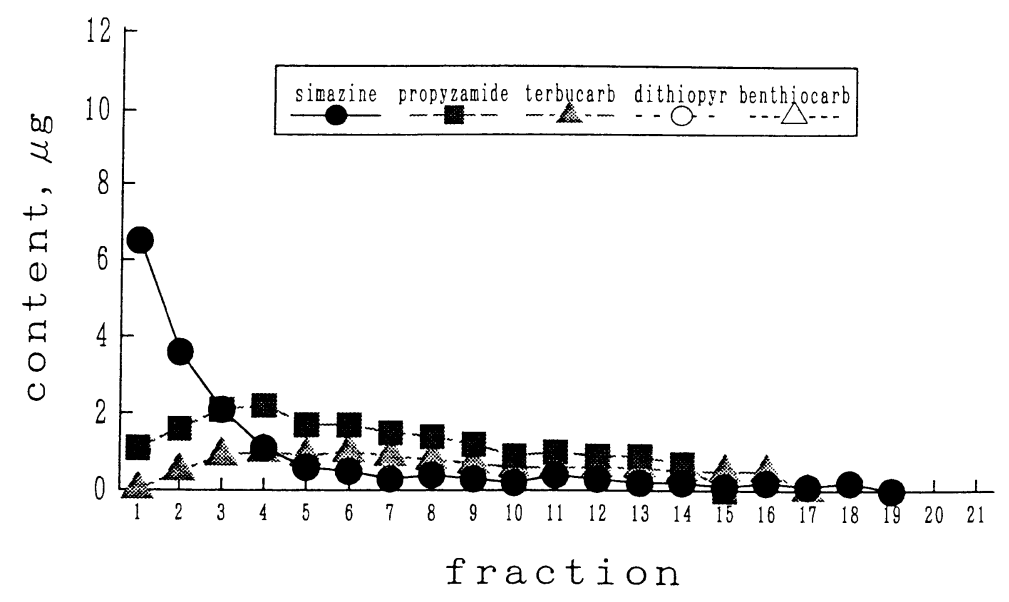

Fig. 5 Efflux behavior of pesticide by column test (in case of fairway 2)

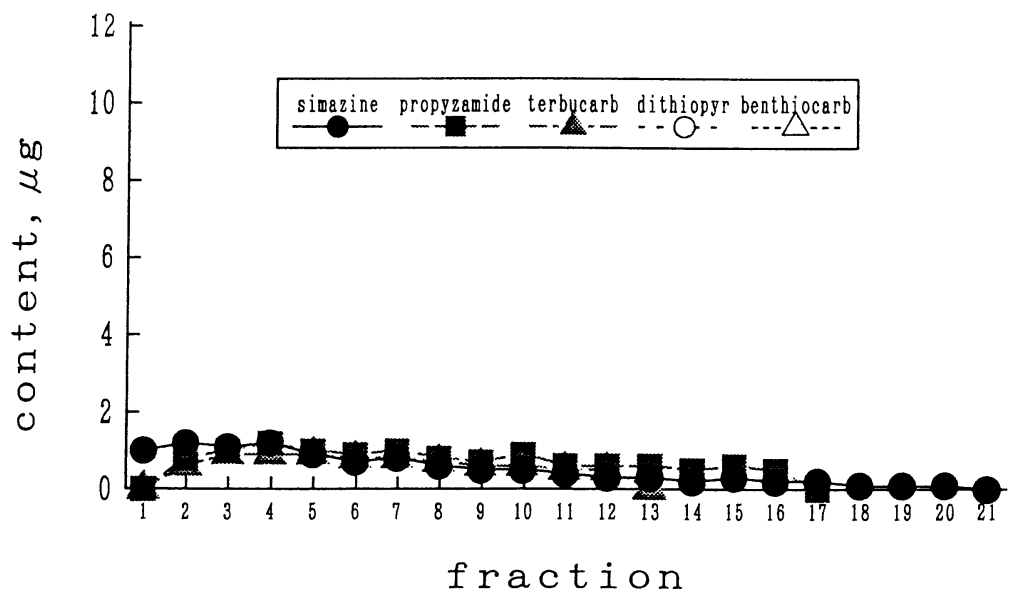

Fig. 6 Efflux behavior of pesticide by column test ( 5 to 1 mixture of Masa and leaf mold)
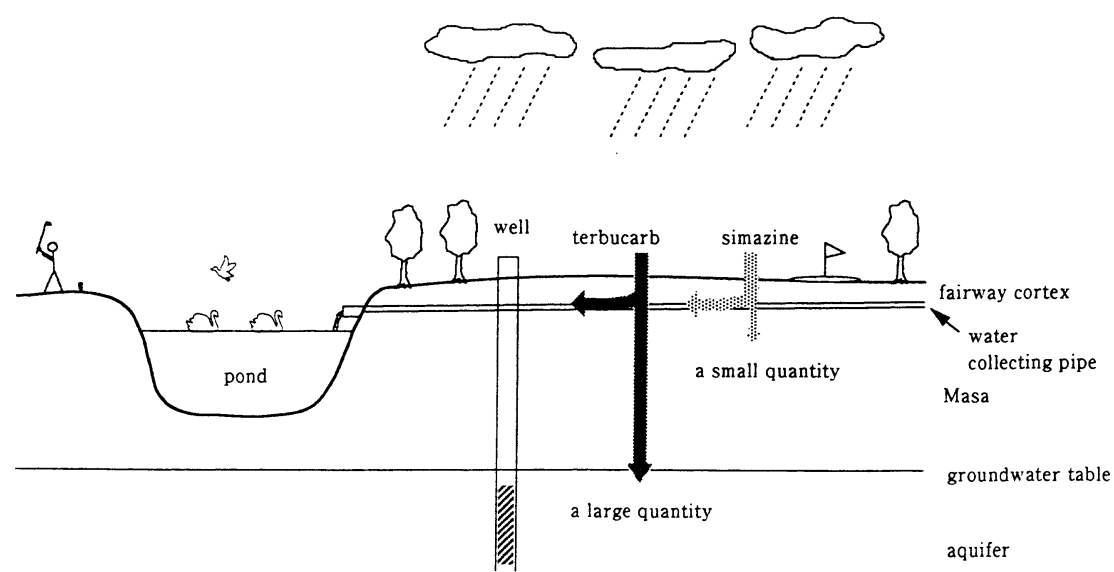

Fig. 7 The efflux situation of pesticide in a golf links fairway (expectation) 
ではテルブカルブの移動速度がシマジンより速いことが 認められ，これが，テルブカルブが井戸水からしばしば 検出される原因であると推定された。

\section{文 献}

1) 厚生省生活衛生局水道環境部長通知：ゴルフ場使用 農薬に係る水道水の安全対策について, 衛水第 152 号, 平成 2 年 5 月 31 日

2 ）厚生省生活衛生局水道環境部長通知：ゴルフ場使用 農薬に係る水道水の安全対策について, 衛水第192 号, 平成 3 年 7 月 30 日

3 ）鈴木俊也, 矢口久美子, 近藤治美, 山岸達典：環境
水中におけるテルブカルブの分解生成物, 第27回日 本水環境学会年会講演集, 254-255（1993）

4 ) 大野健治, 石黑靖尚, 鳥羽峰樹, 田中義人, 永瀬 誠, 北森成治, 近藤紘之：農薬の分解性と環境中で の挙動に関する研究, 第11回全国環境・公害研究所 交流シンポジウム予稿集，17-20（1996）

5 ) Isensee, A. R. and Sadeghi, M.: Laboratory apparatus for studying pesticide leaching in intact soil cores, Chemosphere, 25, 581-590 (1992)

6 ）鍬塚昭三：土壤と農薬, 化学工業, 23, 1489-1496 (1972) 